\title{
EXPRESSION OF SELECTED miRNAs IN CIRCULATING BLOOD OF EARLY AND LATE-ONSET ALZHEIMER DISEASE PATIENTS
}

\author{
ERKEN VE GEÇ BAŞLANGIÇLI ALZHEIMER HASTALARININ PERIFERIK KANLARINDA \\ SEÇILMIŞ miRNA'LARIN ANLATIM DÜZEYI
}

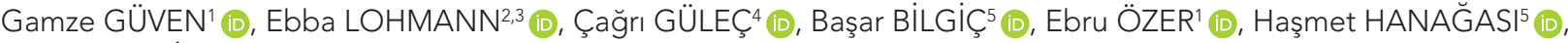 \\ Hakan GÜRVIT ${ }^{5}$, Nihan ÜNALTUNA ${ }^{1}$ iD \\ ${ }^{1}$ Istanbul University, Aziz Sancar Institute of Experimental Medicine, Department of Genetics, Istanbul, Turkey \\ ${ }^{2}$ University of Tübingen, Hertie Institute for Clinical Brain Research, Department of Neurodegenerative Diseases, Germany \\ ${ }^{3}$ DZNE, German Center for Neurodegenerative Diseases, Tübingen, Germany \\ ${ }^{4}$ Istanbul University, Istanbul Faculty of Medicine, Department of Medical Genetics, Istanbul, Turkey \\ ${ }^{5}$ Istanbul University, Istanbul Faculty of Medicine, Department of Neurology, Behavioural Neurology and Movement Disorders Unit, \\ Istanbul, Turkey
}

ORCID IDs of the authors: G.G.0000-0001-8576-5843; E.L.0000-0001-8695-7919; C..G. 0000-0002-1256-9574; B.B.0000-0001-6032-0856; E.Ö.0000-0002-7092-7624; H.H.0000-0001-9645-7707; H.G. 0000-0003-2908-8475; N.Ü.0000-0003-0562-0455

Cite this article as: Guven G, Lohmann E, Gulec C, Bilgic B, Ozer E, Hanagasi H, et al. Expression of selected miRNAs in circulating blood of early and late-onset Alzheimer disease patients. J Ist Faculty Med 2021;84(2):165-74. doi: 10.26650/IUITFD.2020.0061

\section{ABSTRACT}

Objective: Inflammation and associated microRNAs (miRNA) both play essential roles in the pathogenesis of Alzheimer's disease (AD). The expression profile of miRNA's in an AD brain, also reflected in the peripheral blood mononuclear cells, may give support to the inflammatory changes seen in the course of AD. We aimed to investigate the expression levels of specific inflammatory miRNAs (mir-146a, mir-144, mir-34a) in both blood leukocytes and plasma of AD patients and to evaluate their potential usability as biomarkers in AD diagnosis and to also demonstrate whether the expression of these miRNAs differ between early and late-onset AD patients.

Methods: We investigated the expression levels of miRNAs in 16 early-onset and 26 late-onset AD patients and in their respective controls by using qRT-PCR.

Results: Plasma mir-144 levels were significantly different between EOAD and LOAD patients $(p=0.015)$. In addition, levels of leukocyte mir-34a were significantly down-regulated in EOAD compared to LOAD patients ( $p=0.027$ ). Our results also showed significant positive correlations between age and plasma mir144 and leukocyte mir-34a expressions.

Conclusion: The differential expression of plasma mir-144 and leukocyte mir-34a between EOAD and LOAD patients might ref-

\section{ÖZET}

Amaç: Enflamasyon ve ilişkili mikroRNA'lar (miRNA), Alzheimer hastalığının $(\mathrm{AH})$ patogenezinde önemli rol oynamaktadırlar. AH beyininde görülen miRNA'ların anlatım profilindeki değişikliklerin periferal kan mononükleer hücrelerine de yansımış olması, AH sırasında görülen enflamatuar değişikliklerin bir göstergesi olabilir. Bu çalışmada, Alzheimer hastalarının hem periferal lökositlerinde hem de plazmalarında belirli enflamatuvar miRNA'ların (mir-146a, mir-144, mir-34a) anlatım düzeylerindeki değişiklikleri araştırmayı ve ve $\mathrm{AH}$ tanısında biyobelirteç olarak kullanılabillirliklerinin değerlendirilmesini amaçladık. Ayrıca, bu miRNA'ların anlatımlarının erken ve geç başlangıçlı $A H$ arasında farklılık gösterip göstermediğini belirlemeyi amaçladık.

Gereç ve Yöntem: Gerçek zamanlı polimeraz zincir reaksiyonu yöntemini kullanarak 16 erken başlangıçlı ve 26 geç başlangıçlı $\mathrm{AH}$ hastası ve yaş-uyumlu kontrollerinde miRNA'ların anlatım düzeylerini araştırdık.

Bulgular: Plazma mir-144 anlatım düzeyinin erken ve geç başlangıçlı AH hastaları arasında anlamlı farklılık gösterdiğini saptadık $(p=0,015)$. Ek olarak, lökosit mir-34a anlatım düzeyi erken başlangıçlı $A H^{\prime}$ de geç başlangıçlı $\mathrm{AH}$ hastalarına göre anlamlı derecede düşük bulundu $(p=0,027)$. Sonuçlarımız ayrıca, yaş ve plazma mir-144 ( $r=0,319, p=0,02)$ ile lökosit mir-34a

Corresponding author/iletişim kurulacak yazar: zgamzee@gmail.com

Submitted/Başvuru: 15.05.2020 • Revision Requested/Revizyon Talebi: 20.07.2020 •

Last Revision Received/Son Revizyon: 27.08.2020 • Accepted/Kabul: 07.09.2020 • Published Online/Online Yayın: 09.03 .2021 
lect age-dependent changes in miRNA expression and might be independent of the disease status.

Keywords: Alzheimer disease, miRNA, miRNA expression $(r=0,414, p=0,001)$ anlatım düzeyleri arasında anlamlı pozitif korelasyon olduğunu gösterdi.

Sonuç: Bulgularımız erken ve geç başlangıçı AH hastaları arasında plazma mir-144 ve lökosit mir-34a anlatımlarında görülen farklılı̆ın miRNA ekspresyonundaki yaşa bağlı değişiklikleri yansıttığını ve hastalık durumundan bağımsız olabileceğini düşündürmektedir.

Anahtar Kelimeler: Alzheimer hastalığı, miRNA, miRNA anlatımı

\section{INTRODUCTION}

Alzheimer's disease (AD) is a neurodegenerative disease leading to cognitive decline, interfering with the activities of daily living. The main pathological hallmarks of the disease are extracellular protein deposits called amyloid plaques $(A \beta)$ and intracellular deposits called neurofibrillary tangles, consisting of phosphorylated tau protein. Alzheimer's disease is divided into two groups according to the age of onset; early-onset ( $<65$ years old) and late-onset ( $>65$ years old). Early-onset AD (EOAD) is mostly familial and caused by rare mutations in one of three responsible genes: Amyloid precursor protein (APP), Presenilin 1 (PSEN1) and Presenilin 2 (PSEN2). Late-onset AD (LOAD), a more common type of $A D$, is mostly sporadic. Numerous genetic and environmental factors pose risks for the development of $A D$, affecting the age at onset and the progression of the disease. Inflammation is one of the core factors in the pathogenesis of $A D$. The mechanisms underlying the process from $A \beta$ production to neurodegeneration partly depend on fluctuation in the expression of genes involved in inflammation, which suggests the transcriptional and/or post-transcriptional regulation of these genes. One of the regulatory factors that may play a role in this process is the behaviour of small non-coding RNA molecules called micro RNAs (miRNAs) that regulate gene expression in the post-transcriptional stage (1). miRNAs have fine-tuning roles in inflammatory processes, and their expression profiles are known to change in various diseases (2).

Studies have shown that the expression levels of several miRNAs have altered in $A D$ and moreover, these changes have been reported not only in disease-related brain regions (3) but also in peripheral body fluids such as blood, cerebrospinal fluid (CSF), plasma and serum (4). Determination of these changes in peripheral samples enables these miRNAs to be used as non-invasive biomarkers for the early diagnosis of AD. Accordingly, studies have found significant differences in the expression levels of miRNAs, which involved a number of important pathways including inflammation, in peripheral mononuclear cells of Alzheimer's patients (5).

Therefore, in our study we first aimed to investigate whether the expression levels of specific inflammatory miRNAs could be identified in both peripheral blood cells (leukocytes) and cell-free plasma of Alzheimer patients and to evaluate their potential usability as a biomarker in $A D$ diagnosis in the Turkish cohort of AD patients. Secondly, our aim was to determine whether the expression of the selected miRNAs differed between early and late-onset AD.

In the selection of miRNAs included in our study, we considered that they showed altered expression profile in peripheral body fluids of AD patients as well as the fact that they were not previously studied in the Turkish population. Based on this, three candidate miRNAs (mir-146a, mir-144 and mir-34a) known to be involved in inflammatory processes and whose target genes are associated with $A \beta$ metabolism were selected for the study (Table 1). Mir-146a plays a key role in the negative feedback regulation of the inflammatory pathway activated by nuclear factor kappa-light-chain-enhancer of activated B cells (NFkB) by suppressing the expression of its target gene; Interleukin-1 receptor-associated (IRAK1) (6). mir-144 is a negative regulator of ADAM10, a major $\alpha$-secretase responsible for cleaving APP, and up-regulation of mir-144 decreases expression of ADAM10 protein (7). Mir-34a is a NFKB regulated miRNA that is involved in inflammatory processes and through down-regulation of its target gene triggering receptor expressed in myeloid cells 2 (TREM2), it may be involved in AD pathogenesis (8).

\section{MATERIALS AND METHODS}

\section{Patients and controls}

The study population was comprised of 42 Turkish AD patients and 20 Turkish control subjects with no history of any major neurologic and psychiatric disease. Patients were separated into two groups according to age at onset; EOAD $(n=16)$ and $\operatorname{LOAD}(n=26)$ and also controls were divided into two groups as young (age $<65$ yrs, $n=8$ ) and elderly (age $\geq 65 y r s, n=12$ ). Participants were recruited in the Behavioural Neurology and Movement disorders Unit of the Neurology Department. All participants underwent detailed clinical and neuropsychological examination with neuroimaging. The diagnosis of dementia was based on the National Institute of Neurological and Communicative Disorders and Stroke and Alzheimer's disease (9). A Mini Mental State Examination test (MMSE) was used to evaluate the global cognitive status in the 
Table 1: Selected circulating miRNAs specifying their regulation status, source analysed, target genes and detection method

\begin{tabular}{|c|c|c|c|c|c|}
\hline miRNA & Target gene & Source & $\begin{array}{l}\text { miRNA detection } \\
\text { method }\end{array}$ & Status & Reference \\
\hline \multirow[t]{6}{*}{ mir-146 } & \multirow{6}{*}{$\begin{array}{l}\text { TRAF6, IRAK1, } \\
\text { TSPAN12 }\end{array}$} & \multirow[t]{6}{*}{ CSF } & Microarray & increased & (14) \\
\hline & & & qRT-PCR & increased & (25) \\
\hline & & & qRT-PCR & decreased & (16) \\
\hline & & & Microarray & increased & (15) \\
\hline & & & Microarray/qRT-PCR & decreased & (17) \\
\hline & & & qRT-PCR & decreased & (26) \\
\hline \multirow[t]{2}{*}{ mir-144 } & \multirow[t]{2}{*}{ ADAM10 } & \multirow[t]{2}{*}{ blood } & Small RNA seq & decreased & (26) \\
\hline & & & qRT-PCR & decreased & (29) \\
\hline \multirow[t]{7}{*}{ mir-34a } & \multirow[t]{7}{*}{ TREM2, BECLIN1 } & \multirow[t]{2}{*}{ CSF } & qRT-PCR & decreased & (27) \\
\hline & & & Microarray & increased & (19) \\
\hline & & \multirow[t]{3}{*}{ plasma } & qRT-PCR & decreased & (28) \\
\hline & & & qRT-PCR & decreased & (20) \\
\hline & & & qRT-PCR & increased & (30) \\
\hline & & PBMC & qRT-PCR & increased & (18) \\
\hline & & blood & Microarray & increased & (26) \\
\hline
\end{tabular}

$\mathrm{CSF}=$ Cerebrospinal fluid, $\mathrm{PBMC}=$ Peripheral blood mononuclear cell, qRT-PCR=quantitative real-time polymerase chain reaction

participants. The study was approved by the Ethics Committee of the University (Date:12/08/2014, No:1221). The procedures used in this study adhere to the tenets of the Declaration of Helsinki. Informed consent was obtained from the individual participants or the legal guardians of the subjects unable to consent.

\section{Total RNA isolation from blood leukocytes and plasma} $20 \mathrm{ml}$ peripheral blood was collected into EDTA containing tubes to isolate leukocytes and plasma. Blood samples were centrifuged at $1400 \mathrm{xg}$ for $10 \mathrm{~min}$ and separated plasma samples were stored at $-80^{\circ} \mathrm{C}$ for further use. Total RNA was isolated from peripheral blood leukocytes by using a miRNeasy Mini Kit (Qiagen) and from $600 \mu$ l of plasma by using a mirVana PARIS Isolation Kit (Applied Biosystems) according to the manufacturer's instructions. During the first step of the plasma RNA isolation protocol, $0.30 \mathrm{fmols}$ synthetic miRNA-39 from Caenorhabditis elegans celmiR-39 (Qiagen) was added to each sample to normalise and monitor the extraction efficiency in RNA isolation.

\section{Quantitative real-time PCR}

MicroRNAs were transcribed by using the Taqman MicroRNA Reverse Transcription Kit (Applied Biosystems), with specific miRNA stem-loop primers according to the manufacturer's instructions. $15 \mu \mathrm{l}$ reverse transcription (RT) reaction mixture consists of $0.15 \mu \mathrm{l}$ of $100 \mathrm{mM}$ dNTP, $1 \mu$ l of MultiScribe reverse transcriptase ( $50 \mathrm{U} / \mathrm{uL}), 1.5 \mu$ l of $10 \times \mathrm{RT}$ buffer, $0.19 \mu \mathrm{l}$ of RNase inhibitor $(20 \mathrm{U} / \mu \mathrm{l}), 4.16 \mu \mathrm{l}$ of RNasefree water, 3uL of $5 \times$ miRNA-specific stem-loop RT primer and $5 \mu$ l of the RNA sample (1-10ng total RNA). RT reaction for each specific miRNA was performed at $16^{\circ} \mathrm{C}$ for $30 \mathrm{~min}$, at $42^{\circ} \mathrm{C}$ for $30 \mathrm{~min}$, and at $85^{\circ} \mathrm{C}$ for $5 \mathrm{~min}$.

Quantitative real-time polymerase chain reaction (RT-qPCR) was performed to determine the expression levels of miRNAs using the TaqMan MicroRNA Assays (Applied Biosystems). A total of $10 \mu \mathrm{l}$ qPCR reaction mix was composed of $1 \mu$ TaqMan Small RNA Assay (Applied Biosystems), $5 \mu$ LightCycler 480 Probes Master (Roche), 2 $\mu \mathrm{l}$ RNase- free water and $2 \mu \mathrm{l}$ RT reaction product. The qRT-PCR was carried out on a LightCycler 480 system (Roche) under the following conditions: $95^{\circ} \mathrm{C} 10 \mathrm{~min}, 45$ cycles of $95^{\circ} \mathrm{C} 15 \mathrm{~s}$, and $60^{\circ} \mathrm{C} 1 \mathrm{~min}$. All qRT-PCR reactions were run in triplicate. The relative expression level of each miRNA was calculated using the $2^{-\Delta \Delta C t}$ method. RNU48 was used as an endogenous control in $2^{-\Delta \Delta C t} \mathrm{calcu}-$ lations for the leukocyte samples. The Ct values of plasma samples were first normalised against cel-miR-39 and then against RNU6, as described previously (10).

\section{Statistical analysis}

Relative mRNA levels between groups were compared using a two-tailed Mann-Whitney $U$ test. Correlations of miRNA levels with age and MMSE in all subjects and correlations of miRNA levels with age at onset in AD patients 
were analysed using Spearman's correlation test. Descriptive statistical analysis of the groups was performed with an $\chi 2$ test for the categorical variables, and a Student's $t$ test for the continuous variables. We used receiver operating characteristic (ROC) curve analysis and calculated the area under the curve (AUC) of the miRNAs to evaluate their sensitivity and specificity for distinguishing $A D$ from controls or EOAD from LOAD. The criterion for significance was set at $p<0.05$. The stability of the candidate reference gene expression in groups was evaluated by the NormFinder (11) and BestKeeper (12) programs. All statistical analyses were performed with SPSS 21.0 software (IBM Corp, Armonk, NY, USA).

\section{RESULTS}

\section{Characteristics of the study group}

Demographic and clinical characteristics of the subjects are summarised in Table 2. As shown in table 2, mean MMSE scores were similar between EOAD and LOAD groups but as expected, lower than their age-matched controls.

\section{miRNA expression levels mir-146a levels}

The plasma and leukocyte expression levels of mir-146a did not show a significant difference between any of the $\mathrm{AD}$ patients and controls. Figure 1 shows plasma and leukocyte mir-146 expression in EOAD, LOAD groups and

Table 2: Descriptive characteristics of patient groups and controls

\begin{tabular}{|c|c|c|c|c|c|c|}
\hline & $\begin{array}{l}\text { EOAD } \\
(n=16)\end{array}$ & $\begin{array}{l}\text { Young controls } \\
\qquad(n=8)\end{array}$ & $\mathrm{p}$-value & $\begin{array}{l}\text { LOAD } \\
(n=26)\end{array}$ & $\begin{array}{l}\text { Elderly controls } \\
\qquad(n=12)\end{array}$ & $\mathrm{p}$-value \\
\hline $\begin{array}{l}\text { Age at recruitment, } \\
\text { years }\end{array}$ & $58.3 \pm 9.6$ & $54.25 \pm 8.44$ & 0.33 & $76.5 \pm 4.4$ & $73.7 \pm 5.3$ & 0.09 \\
\hline Age of onset, years & $53 \pm 8.8$ & & & $71.6 \pm 4.5$ & & \\
\hline \multicolumn{7}{|l|}{ Gender, n (\%) } \\
\hline Male & $4(25)$ & $4(50)$ & \multirow{2}{*}{0.22} & 9 (34.6) & $5(41.7)$ & \multirow{2}{*}{0.67} \\
\hline Female & $12(75)$ & $4(50)$ & & $17(65.4)$ & $7(58.3)$ & \\
\hline MMSE score & $16.4 \pm 7.7(n=12)$ & $28.25 \pm 1.2(n=4)$ & 0.009 & $17.7 \pm 6.0(n=25)$ & $28.45 \pm 1.5(n=11)$ & $<0.001$ \\
\hline \multicolumn{7}{|c|}{ APOE $\varepsilon 4$ status, $n(\%)$} \\
\hline$\varepsilon 4$ carrier & $6(40)$ & $2(25)$ & \multirow{2}{*}{0.47} & $12(46.2)$ & $2(16.7)$ & \multirow{2}{*}{0.08} \\
\hline$\varepsilon 4$ non-carrier & $9(60)$ & $6(75)$ & & 14 (53.8) & $10(83.3)$ & \\
\hline
\end{tabular}

Continuous variables are presented as mean $\pm \mathrm{SD}$ and dichotomous variables as percentage. A t-test was used for comparison of means and $\chi^{2}$ test for percentages. Abbreviations: $A D=$ Alzheimer's disease, MMSE=Mini mental state examination, $n=$ number of individuals

a

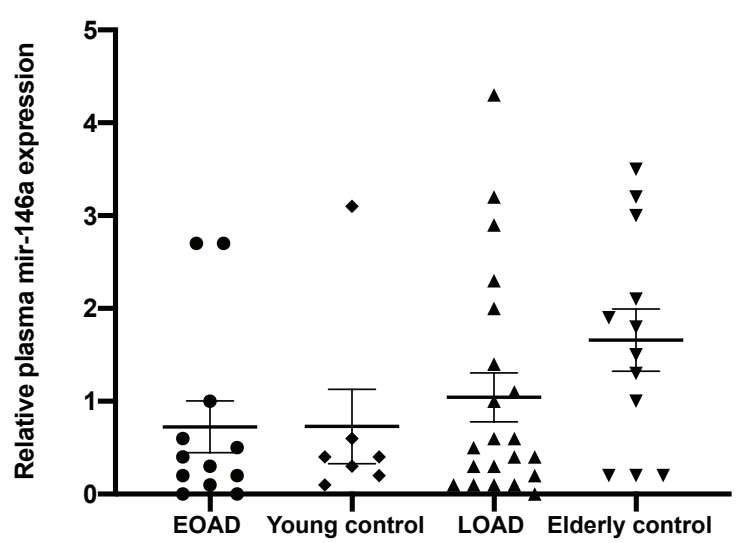

b

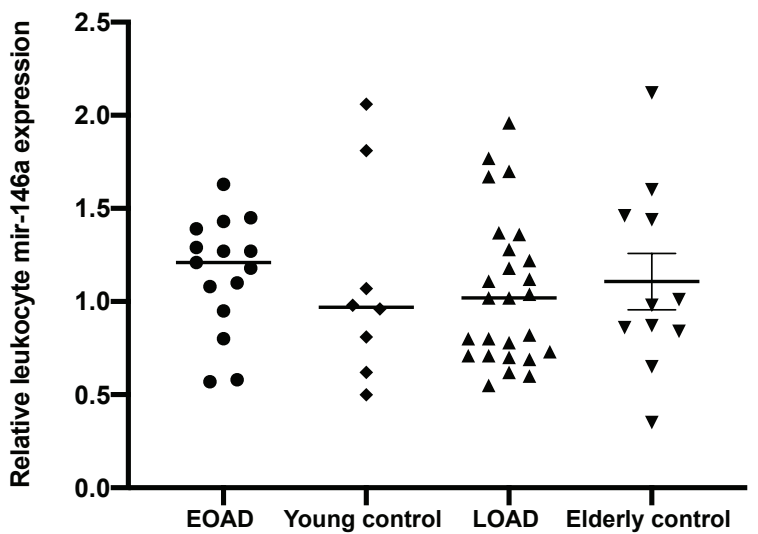

Figure 1: Plasma (a) and leukocyte (b) mir-146a levels in EOAD, LOAD, young and elderly controls. Data are presented as a scatter plot with mean \pm SEM. EOAD=Early-onset Alzheimer Disease, LOAD=Late-onset Alzheimer Disease. plasma mir-146a: EOAD vs young control $p=0.766$, LOAD vs elderly control $p=0.111$, EOAD vs $L O A D p=0.388$, young control vs elderly control $p=0.116$; leukocyte mir-146a: $E O A D$ vs young control $p=0.401$, LOAD vs elderly control $p=0.690$, $E O A D$ vs $L O A D p=0.273$, young control vs elderly control $p=0.836$ 
their respective controls. Plasma mir-146a expression in EOAD group (mean \pm SEM; $0.725 \pm 0.28$ ) was similar to young controls (mean \pm SEM; $0.729 \pm 0.39, p=0.766$ ) but lower levels of mir-146a were observed in LOAD group (mean \pm SEM; 1.04 \pm 0.26 ) than elderly controls (mean \pm SEM; $1.66 \pm 0.33)$, without any significance $(p=0.111$; Figure $1 a)$. Also, there was no significant difference between EOAD and LOAD patients, in terms of plasma mir-146a expression levels $(p=0.388)$. As shown in Figure 1b, leukocyte mir146 a expression was similar between EOAD (mean \pm SEM; $1.15 \pm 0.08$ ) and young controls (mean \pm SEM; 1.10 \pm 0.19 , $\mathrm{p}=0.401$ ), also similar between LOAD (mean \pm SEM; $1.05 \pm 0.08$ ) and elderly controls (mean \pm SEM; 1.10 \pm 0.15 , $\mathrm{p}=0.690$ ). In addition, there was no significant difference between the EOAD and LOAD groups $(p=0.273)$.

\section{mir-144 levels}

The plasma and leukocyte expression levels of mir-144 did not show any significant difference between AD patients and controls. Figure 2 shows plasma and leukocyte mir-144 expression in EOAD, LOAD groups and their respective controls. Plasma mir-144 levels did not differ significantly in EOAD (mean \pm SEM; 0.54 \pm 0.19 ) compared to young controls (mean \pm SEM; $0.82 \pm 0.32, p=0.366$ ) and in LOAD (mean $\pm S E M$; 2.94 \pm 0.74 ) compared to elderly controls (mean \pm SEM; $3.14 \pm 1.17, p=0.946$ ) but there was a significant decrease in EOAD compared to LOAD $(p=0.015$; Figure 2a). Also, plasma mir-144 expression seems to be decreased in young controls compared with elderly, but this was not statistically significant ( $p=0.178)$. As shown in Figure 2b, leukocyte mir-144 levels in EOAD (mean \pm SEM; 0.99 \pm 0.22 ) and young controls (mean \pm SEM; $0.89 \pm 0.17)$ were similar $(p=0.746)$. Also, no significant difference between the LOAD (mean \pm SEM; 1.46 \pm 0.27 ) and elderly controls (mean \pm SEM; $1.77 \pm 0.45$ ) were found $(p=0.637)$. Although the leukocyte mir-144 level seems to decrease in EOAD patients compared to LOAD patients, no significant difference was found $(p=0.787)$. In addition, a lower leukocyte mir-144 level was observed in the young controls than in the elderly controls without any significance $(p=0.537)$.

\section{mir-34a levels}

The plasma and leukocyte expression levels of mir-34a did not show any significant difference between the $A D$ patients and the controls. Figure 3 shows plasma and leukocyte mir-34a expression in EOAD, LOAD groups and their respective controls. Plasma mir-34a expression did not show a significant difference between EOAD (mean $\pm S E M ; 1.20 \pm 0.32$ ) and young controls (mean \pm SEM; 0.94 $\pm 0.42, p=0.623$ ) but mir-34a expression seems to decrease in LOAD (mean \pm SEM; $1.57 \pm 0.48$ ) compared to elderly controls (mean \pm SEM; $2.35 \pm 0.76$ ) without any significance ( $p=0.293$; Figure 3a). Besides, plasma mir-34a expression was similar between the EOAD and LOAD groups $(p=1.000)$. As shown in Figure 3b Leukocyte mir-34a levels did not differ significantly in $\mathrm{EOAD}$ (mean \pm SEM; 0.98 \pm 0.17 ) compared to young controls (mean \pm SEM; $1.04 \pm 0.18, \mathrm{p}=0.481$ ) and in LOAD (mean \pm SEM; $1.17 \pm 0.07$ ) compared to elderly controls (mean \pm SEM; $1.39 \pm 0.2 ; p=0.420$ ) but it was significantly decreased in the EOAD patients compared with the LOAD patients $(p=0.027)$. In addition, leukocyte mir-34a expression seems to decrease in the young controls compared with the elderly, but this was not statistically significant $(p=0.342)$. a

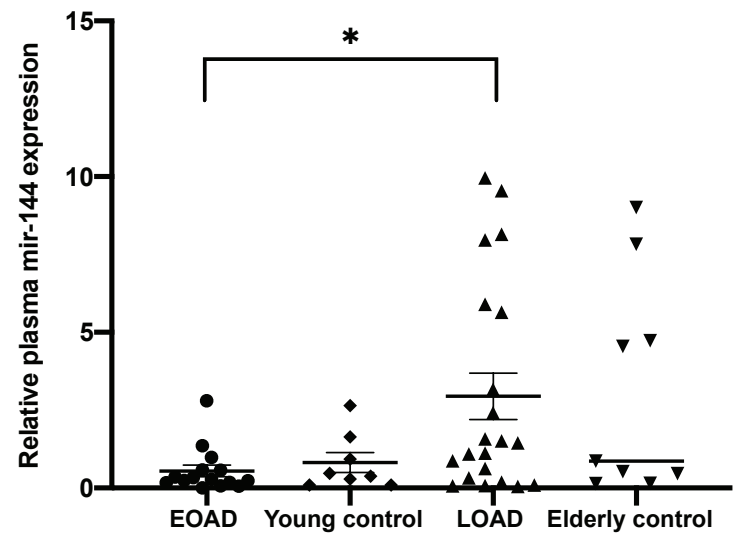

b

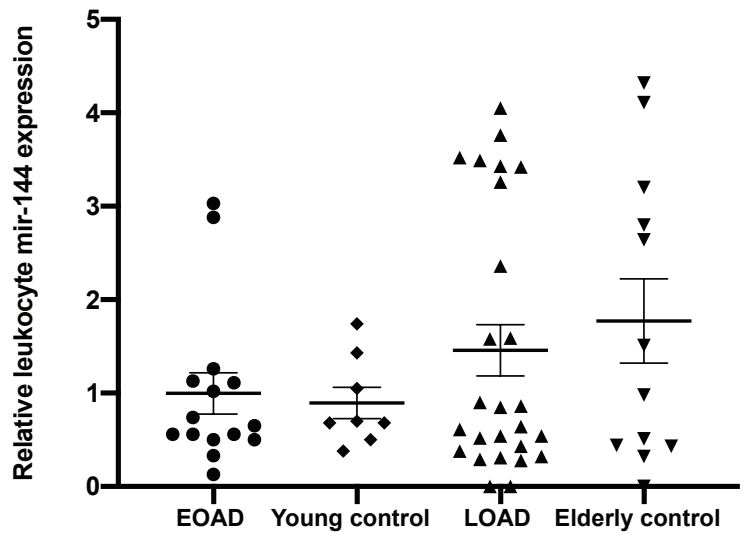

Figure 2: Plasma (a) and leukocyte (b) mir-144 levels in EOAD, LOAD, young and elderly controls. Data are presented as a scatter plot with mean \pm SEM. * $\mathrm{p} \leq 0.05, \mathrm{EOAD}=$ Early-onset Alzheimer Disease, LOAD=Late-onset Alzheimer Disease. plasma mir-144: $E O A D$ vs young control $p=0.366$, LOAD vs elderly control $p=0.946, E O A D$ vs $L O A D p=0.015$, young control vs elderly control $p=0.178$; leukocyte mir-144: EOAD vs young control $p=0.746$, LOAD vs elderly control $p=0.637$, EOAD vs LOAD $p=0.787$, young control vs elderly control $p=0.537$ 
a

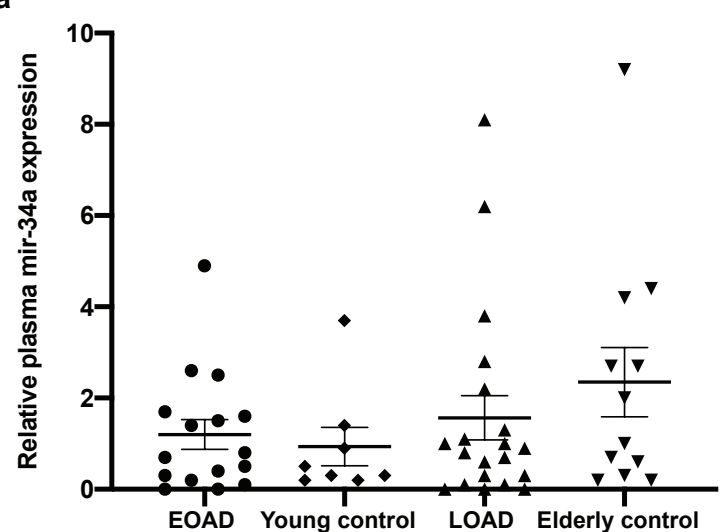

b

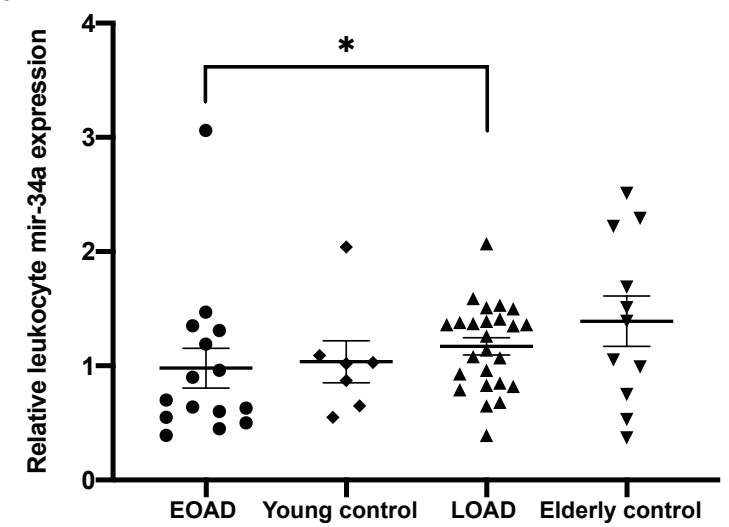

Figure 3: Plasma (a) and leukocyte (b) mir-34a levels in EOAD, LOAD, young and elderly controls. Data are presented as a scatter plot with mean \pm SEM. ${ }^{\star} \mathrm{p} \leq 0.05, \mathrm{EOAD}=$ Early-onset Alzheimer Disease, LOAD=Late-onset Alzheimer Disease. plasma mir-34a: $E O A D$ vs young control $p=0.623$, $L O A D$ vs elderly control $p=0.293, E O A D$ vs $L O A D p=1.000$, young control vs elderly control $p=0.163$; leukocyte mir-34a: $E O A D$ vs young control $p=0.481$, LOAD vs elderly control $p=0.420$, EOAD vs LOAD $p=0.027$, young control vs elderly control $p=0.342$

\section{ROC curve analysis}

To evaluate the sensitivity and specificity of the significantly altered miRNAs, a receiver operating characteristic (ROC) curve analysis was used. The ROC curve analysis and calculated area under the curve (AUC) of significant miRNAs are presented in Table 3. Both plasma mir-144 and leukocyte mir-34a were sensitive to distinguish LOAD from EOAD (Figure 4a-b). The AUC for plasma mir-144 was 0.741 (95\% Cl, 0.577-0.905), with $71.4 \%$ sensitivity and $80 \%$ specificity. Similarly, the AUC for leukocyte mir-34a was 0.711 ( $95 \% \mathrm{Cl}, 0.533-0.888)$, with $44 \%$ sensitivity and $86.7 \%$ specificity. However, the diagnostic power values of plasma mir-144 and leukocyte mir-34a in differentiation of EOAD or LOAD patients from controls as measured by AUC were lower than 0.70, indicating poor diagnostic value for distinguishing the patients from the controls (Table 3). As we performed ROC analysis for both miRNAs in all young and elderly individuals regardless of the disease status, both miRNAs were sensitive to distinguish young individuals from elderly, the AUC for plasma mir144 was 0.711 (95\% Cl, 0.572-0.850), with $56.7 \%$ sensitivity and $82.6 \%$ specificity and the AUC for leukocyte mir-34a was 0.684 (95\% Cl, 0.540-0.829), with $63.9 \%$ sensitivity and $68.2 \%$ specificity.

\section{Correlation analysis}

Since the expression levels of the miRNAs may vary depending on age and the MMSE score, the relationship

Table 3: The receiver operating characteristic (ROC) curve analysis of significant miRNAs

\begin{tabular}{|c|c|c|c|c|c|c|c|}
\hline & Cutoff value & AUC & Sensivity & Specificity & $95 \% \mathrm{Cl}$ & $\mathrm{p}$-value & Distinguish between \\
\hline \multirow{5}{*}{ 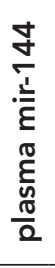 } & $\leq 0.58$ & 0.741 & 0.714 & 0.800 & $0.577-0.905$ & 0.015 & EOAD from LOAD \\
\hline & $<0.38$ & 0.617 & 0.625 & 0.667 & $0.371-0.862$ & 0.366 & EOAD from young control \\
\hline & $<4.55$ & 0.492 & 0.444 & 0.714 & $0.265-0.719$ & 0.946 & LOAD from elderly control \\
\hline & $<0.53$ & 0.694 & 0.667 & 0.625 & $0.438-0.951$ & 0.178 & young control from elderly control \\
\hline & $<1.09$ & 0.711 & 0.567 & 0.826 & $0.572-0.850$ & 0.009 & young subjects from elderly subjects \\
\hline \multirow{5}{*}{ 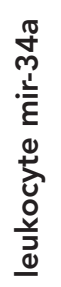 } & $<1.36$ & 0.711 & 0.440 & 0.867 & $0.533-0.888$ & 0.027 & EOAD from LOAD \\
\hline & $<1.02$ & 0.595 & 0.571 & 0.667 & $0.353-0.837$ & 0.481 & EOAD from young control \\
\hline & $\leq 1.39$ & 0.585 & 0.545 & 0.720 & $0.342-0.829$ & 0.420 & LOAD from elderly control \\
\hline & $<1.05$ & 0.636 & 0.636 & 0.714 & $0.375-0.898$ & 0.342 & young control from elderly control \\
\hline & $<1.05$ & 0.684 & 0.639 & 0.682 & $0.540-0.829$ & 0.019 & young subjects from elderly subjects \\
\hline
\end{tabular}

$\mathrm{AUC}=$ Area under curve, $\mathrm{Cl}=$ Confidence interval 
a

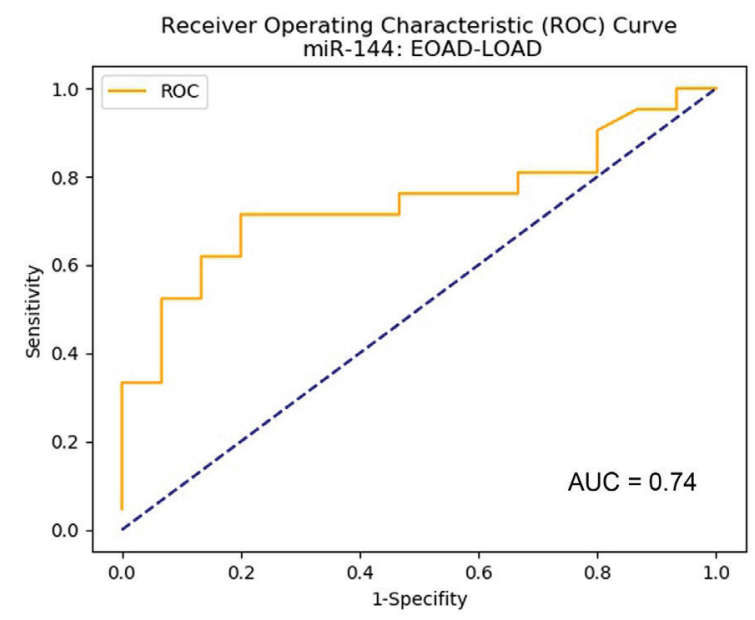

b

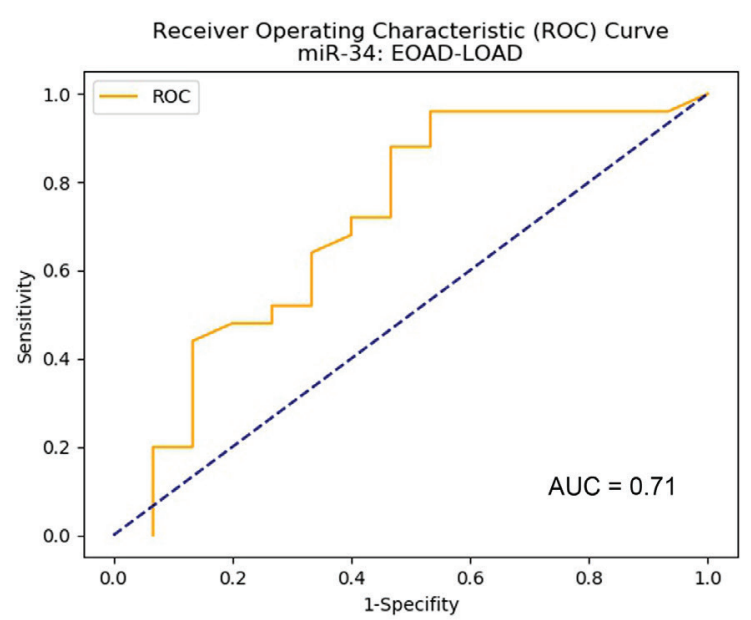

Figure 4: The receiver operating characteristic (ROC) curve plots of plasma mir-144 (a) and leukocyte mir-34a (b) for discriminative ability between EOAD and LOAD. AUC=Area under curve

between age, age of onset, MMSE and the expression levels of the miRNAs were examined by correlation analysis. The correlation analyses pointed out that plasma mir144 levels were positively correlated with age and age of onset $(r=0.319, p=0.02 ; r=0.343, p=0.041$; respectively; Figure 5a-b). Also, leukocyte mir-34a expression lev- els were positively correlated with age and age of onset ( $r=0.414, p=0.001 ; r=0.399, p=0.011$; respectively; Figure $5 c-d)$. There was no significant correlation between age, age of onset and levels of other miRNAs. No significant correlation was found between the MMSE score and levels of miRNAs.

\section{A}

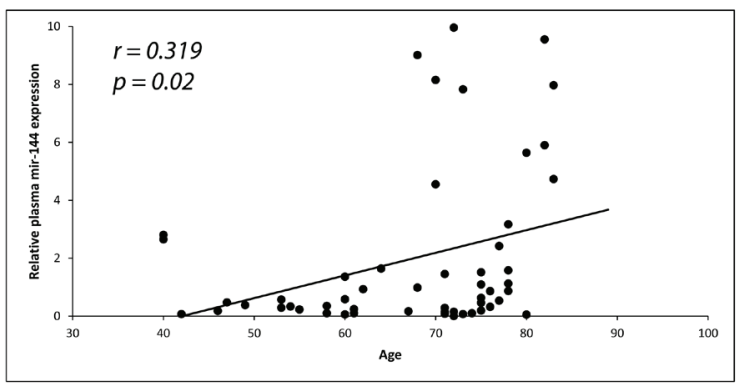

C

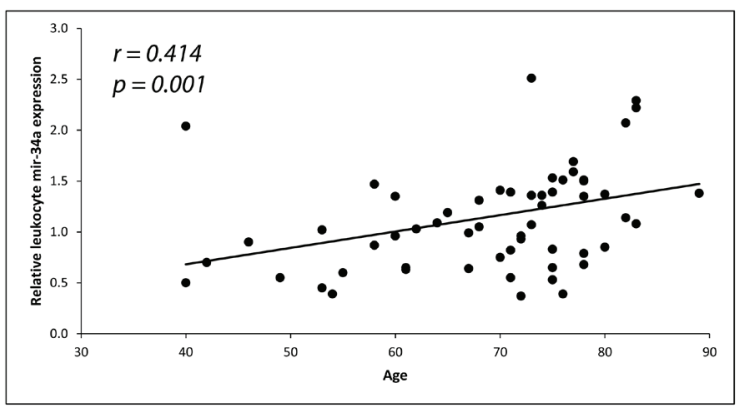

B

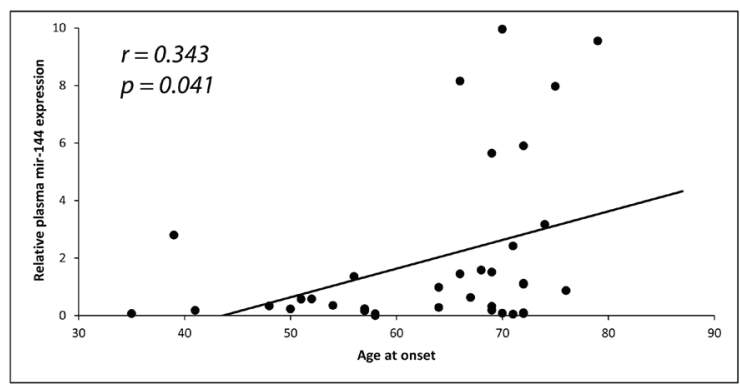

D

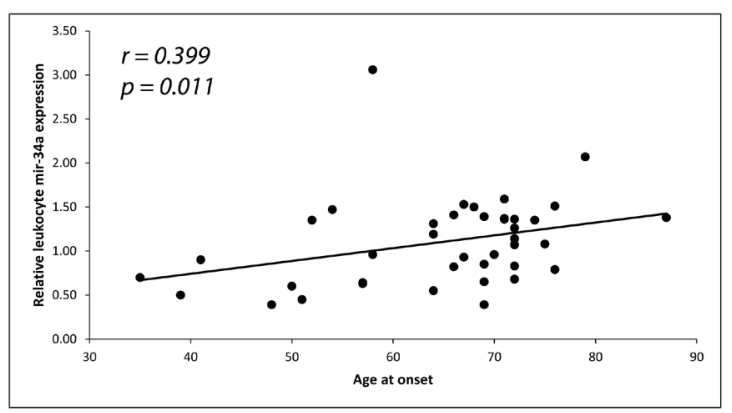

Figure 5: Correlations of plasma mir-144 and leukocyte mir-34a expression levels with age (a-c) and age at onset (b-d). age at onset, r:Spearman's correlation coefficient 


\section{DISCUSSION}

The present work is a preliminary study with a small number of patients and miRNAs. We aimed to perform a comparative analysis of the selected miRNAs, the expression of which are known to change in AD patients. Therefore, we focused on three circulating miRNA (mir-146a, mir-144 and mir-34a) which were previously identified in microarray or RNA sequencing studies. The first aim of this study was to test whether the expression of specific miRNAs could be identified in both the cellular component (leukocyte) and cell-free plasma, and could serve as a peripheral biomarker in AD diagnosis. Then secondly, our next aim was to determine the expression levels of the selected miRNAs in $A D$ patients and whether they differed in EOAD and LOAD. Distinct from previous studies where these miRNAs were investigated, our study is the first comparative study dealing with the cellular origin of the selected miRNAs. Since the cellular origin of a biomarker miRNA is important to explain the mechanism of the relation between the biomarker-miRNA and the disease, we used both cellular (leukocyte) and free (plasma) miRNA. Furthermore, the expression levels of some miRNAs are known to differ among populations (13) and to the best of our knowledge, the selected miRNAs have not been investigated within the Turkish population. Therefore, our study is the first in literature to investigate the mentioned miRNAs in Turkish AD patients.

AD-related alterations in the expression of miRNAs have been described by several studies and these alterations have been reported not only in disease-related brain regions but also in peripheral body fluids such as CSF (14-17), blood (18), plasma (19) and serum (20). Compared to brain tissue, peripheral samples, including blood, plasma, and serum are much easier to collect and determination of miRNA expression profiles in peripheral components enables these miRNAs to be used as a source of non-invasive biomarkers in $A D$ diagnosis. So far, there has only been one study in literature to investigate the expression levels of miRNAs in Turkish AD patients (21). In their study Yılmaz et al. examined seven miRNAs (mir9-5p, mir-29a-3p, mir-106a-5p, mir-106b-5p, mir-107, mir$125 a-3 p$, and mir-125b-5p) whose target genes were associated with the $A \beta$ pathway, in blood samples of $A D$ patients. They found that the expression levels of mir9-5p, 106a-5p, mir-106b-5p and mir-107 were down-regulated in $A D$ patients and indicated that these miRNAs conferred a protection against AD.

Mir-146a expression levels were reported to increase in AD mouse models and human AD brain $(22,23)$. Also, it has been shown that the expression of mir-146a was higher in the hippocampus and neocortex regions of a human $A D$ brain, and the increase in the mir-146 level was associated with the severity of AD pathology (24). Higher levels of mir- 146a were also reported in $\operatorname{CSF}(14,15,25)$, plasma (19) and serum (20) samples of AD patients; on the contrary, lower levels of mir-146a were observed both in CSF (16, $17,26)$, plasma $(26,27)$ and serum $(28)$. A study by Kiko et al. showed decreased levels of plasma mir-146a in elderly AD patients (mean age:80.7 yrs) (15). However, that study included a small sample size, and there was a significant difference in age between patients and controls. A recent study by Maffioletti et al. showed no significant association in plasma mir-146a levels comparing AD patients and agematched controls (29). Strikingly, in their study, Maffioletti et al. observed significantly higher mir-146a levels when AD patients were compared with age-unmatched controls (29). Furthermore, they found a positive correlation between mir-146a levels and age, which pointed out the influence of ageing on peripheral mir-146a levels. In these two studies, the mean ages of AD patients (80.7 and 74.6 years) were similar to the mean age of our LOAD patients (76.5 years). Unlike the study by Kiko et al. but in line with Maffioletti et al., we did not find a significant difference in plasma levels of mir-146a between LOAD patients and elderly controls $(26,29)$. Although there have been a few studies analysing plasma mir-146 expression in AD patients, such a study in blood leukocytes has not been performed so far. Therefore, our study is the first to examine leukocytes mir-146 expression in AD patients and we have found that the expression of leukocyte mir-146a does not significantly differ between each group, but is very similar. Overall, we can suggest that the differential expression of mir-146a detected in a human AD brain may not be present in leukocytes or plasma. However, it should be taken into consideration that our study and other studies investigating the peripheral mir-146a levels in AD patients were performed in small study cohorts.

Previously, mir-144 expression was found to be down-regulated in blood samples of AD patients $(18,30)$. Unlike Satoh et al., we found that blood mir-144 levels did not differ in early and late-onset patients compared to their age-matched controls. However, our study was conducted on a relatively small sample size compared with that of Satoh et al., thus, further research in larger cohorts will be needed to validate the reported results (30). Plasma mir-144 levels in AD patients have not been examined so far. Our results showed no significant difference in early and late-onset patients compared to their age-matched controls but we observed significantly increased plasma mir-144 levels in LOAD patients when compared with EOAD, and this increase was also detected in leukocytes although statistically non-significant. Moreover, we found that plasma mir-144 levels were positively correlated with age. Up-regulation of miR-144 was reported in the ageing primate cerebellum and cortex and also in the cortex of human AD brain (31). The increase of miR-144 levels suggested that miR-144 may play a regulatory role in the post-transcriptional regulation of certain genes in the 
ageing brain (32). In line with this finding, both in plasma and leukocyte samples we observed lower levels of mir-144 in young controls than in elderly controls but due to the low number of individuals in each group, this decrease did not reach a statistical significance. Therefore, we can suggest that the differential expression of mir-144 between EOAD and LOAD groups might be independent of the disease status and results from an age-dependent increase in mir-144 expression.

mir-34a is up-regulated in the hippocampus of an $A D$ brain (33) and the increased expression of miR-34a in $A D$ brains correlated with the severity of $A D$ pathology (34). Alterations in the expression of mir-34a were described in plasma samples of $A D$ patients, although with contradictory results $(10,26,27)$. Two studies $(26,27)$ showed lower levels of plasma mir-34a in AD patients while in one study, higher levels were observed (10). Unlike these studies, we did not find a significant difference in plasma mir-34a levels in early and late-onset patients compared to their age-matched controls. So far, two studies have investigated mir-34a expression in blood cells of AD patients $(5,10)$. In both studies, analyses were performed in elderly $A D$ patients and higher mir-34a levels were observed. However, in our study blood leukocyte levels of mir-34a were not different in neither the EOAD nor the LOAD group compared to their respective controls. Strikingly, leukocyte mir34-a expression in EOAD patients was significantly lower than the expression in LOAD patients. Furthermore, young controls seem to have lower levels of leukocyte mir34-a expression than elderly controls. Thus, we can suggest that this differential expression of mir-34a between EOAD and LOAD might be due to the age-dependent changes in expression of mir34-a (35). In addition, the significant positive correlation of mir-34a expression with age was another finding of our study, in line with this evidence. Since studies examining peripheral mir-34a expression showed contradictory results, further studies are needed to clarify the role of mir-34a in AD.

To be used as a biomarker, a miRNA level is expected to have sufficient levels of specificity and sensitivity. Though our data demonstrated that relative expression levels of plasma mir-144 and leukocyte mir-34a seemed to distinguish EOAD from LOAD with significant specificity and sensitivity, these findings were due to dependence of both miRNAs on the age, consistent with the results of the correlation analyses.

In conclusion, our results could suggest that the differential expression of miRNAs between EOAD and LOAD groups might be independent of the AD disease status and result from age-dependent changes. Also, altered expression of miRNAs in the brain may not be correlated in plasma or blood cells. The relatively small sample size is the main limitation of our study. Future studies with larger cohorts are needed to validate results reported here, and reveal whether miRNA changes specific to EOAD and LOAD could be used as a biomarker.

Ethics Committee Approval: This study was approved by the Ethical Committee of the Istanbul University, Istanbul Faculty of Medicine (Date:12.08.2014, No:1221).

Informed Consent: Written consent was obtained from the participants.

Peer Review: Externally peer-reviewed.

Author Contributions: Conception/Design of Study- G.G. Ç.G.; Data Acquisition- G.G., E.Ö., E.L., B.B., H.G., H.H.; Data Analysis/Interpretation- G.G., Ç.G., N.Ü.; Drafting ManuscriptG.G., B.B., E.L. Ç.G.; Critical Revision of Manuscript- H.H., H.G., E.Ö., N.Ü.; Final Approval and Accountability- G.G., E.L., Ç.G., B.B., E.Ö., H.H., H.G., N.Ü.

Conflict of Interest: Authors declared no conflict of interest.

Financial Disclosure: This study was supported by Istanbul University Scientific Research Projects (Project No:48601)

Etik Komite Onayı: Bu çalışma için etik komite onayı İstanbul Üniversitesi, İstanbul Tıp Fakültesi Etik Kurulu'ndan alınmıştır (Tarih:12.08.2014, Sayı:1221).

Bilgilendirilmiş Onam: Katılımcılardan bilgilendirilmiş onam alınmıştır.

Hakem Değerlendirmesi: Dış bağımsız.

Yazar Katkıları: Çalışma Konsepti/Tasarım- G.G., Ç.G.; Veri Toplama- G.G., E.Ö., E.L., B.B., H.G., H.H.; Veri Analizi/Yorumlama- G.G., Ç.G., N.Ü.; Yazı Taslağı- G.G., B.B., E.L. Ç.G.; İçeriğin Eleştirel İncelemesi- H.H., H.G., E.Ö., N.Ü.; Son Onay ve Sorumluluk- G.G., E.L., Ç.G., B.B., E.Ö., H.H., H.G., N.Ü.

Çıkar Çatışması: Yazarlar çıkar çatışması beyan etmemişlerdir.

Finansal Destek: Bu çalışma İstanbul Üniversitesi Bilimsel Araştırma Projeleri kapsamında desteklenmiştir (Proje No:48601).

\section{REFERENCES}

1. O'Carroll D, Schaefer A. General principals of miRNA biogenesis and regulation in the brain. Neuropsychopharmacology 2013;(38):39-54. [CrossRef]

2. Li Y, Kowdley KV. MicroRNAs in common human diseases. Genomics Proteomics Bioinformatics 2012;10(5):246-253. [CrossRef]

3. Wang M, Qin L, Tang B. MicroRNAs in Alzheimer's Disease. Front Genet 2019;(10):153. [CrossRef]

4. Swarbrick S, Wragg N, Ghosh S, Stolzing A. Systematic Review of miRNA as Biomarkers in Alzheimer's Disease. Mol Neurobiol 2019;56(9):6156-67. [CrossRef]

5. Schipper HM, Maes OC, Chertkow HM, Wang E. MicroRNA expression in Alzheimer blood mononuclear cells. Gene Regul Syst Bio 2007;1:263-74. [CrossRef] 
6. Taganov KD, Boldin MP, Chang KJ, Baltimore D. NF-kappaBdependent induction of microRNA miR-146, an inhibitor targeted to signaling proteins of innate immune responses. Proc Natl Acad Sci U S A 2006;103(33):12481-6. [CrossRef]

7. Cheng C, Li W, Zhang Z, Yoshimura S, Hao Q, Zhang C et al. MicroRNA-144 is regulated by activator protein-1 (AP-1) and decreases expression of Alzheimer disease-related a disintegrin and metalloprotease 10 (ADAM10). J Biol Chem 2013;288(19):13748-61. [CrossRef]

8. Zhao Y, Bhattacharjee S, Jones BM, Dua P, Alexandrov PN, Hill JM, et al. Regulation of TREM2 expression by an NF-кBsensitive miRNA-34a. Neuroreport 2013;24(6):318-23. [CrossRef]

9. McKhann GM, Knopman DS, Chertkow H, Hyman BT, Jack $\mathrm{CR} \mathrm{Jr}$, Kawas $\mathrm{CH}$, et al. The diagnosis of dementia due to Alzheimer's disease: recommendations from the National Institute on Aging-Alzheimer's Association workgroups on diagnostic guidelines for Alzheimer's disease. Alzheimers Dement 2011;7(3):263-9. [CrossRef]

10. Bhatnagar S, Chertkow H, Schipper HM, Yuan Z, Shetty $V$, Jenkins $S$, Jones $T$, Wang $E$. Increased microRNA-34c abundance in Alzheimer's disease circulating blood plasma. Front Mol Neurosci 2014;7:2. [CrossRef]

11. Andersen $\mathrm{CL}$, Ledet-Jensen J, Ørntoft T. Normalization of real-time quantitative RT-PCR data: a model based variance estimation approach to identify genes suited for normalization - applied to bladder- and colon-cancer datasets. Cancer Research 2004;64(15):5245-50. [CrossRef]

12. Pfaffl MW, Tichopád A, Prgomet C, Neuvians TP. Determination of stable housekeeping genes, differentially regulated target genes and sample integrity: BestKeeper Excel-based tool using pair-wise correlations. Biotechnology Lett. 2004;26(6):509-15. [CrossRef]

13. Huang RS, Gamazon ER, Ziliak D, Wen Y, Im HK, Zhang W, et al. Population differences in microRNA expression and biological implications. RNA Biology 2011;8(4):692-701. [CrossRef]

14. Alexandrov PN, Dua $P$, Hill JM, Bhattacharjee $S$, Zhao $Y$, Lukiw WJ. microRNA (miRNA) speciation in Alzheimer's disease (AD) cerebrospinal fluid (CSF) and extracellular fluid (ECF). Int J Biochem Mol Biol 2012;3(4):365-73.

15. Lukiw WJ, Alexandrov PN, Zhao Y, Hill JM, Bhattacharjee S. Spreading of Alzheimer's disease inflammatory signaling through soluble micro-RNA. Neuroreport 2012;23(10):62126. [CrossRef]

16. Müller M, Kuiperij HB, Claassen JA, Kusters B, Verbeek MM. MicroRNAs in Alzheimer's disease: Differential expression in hippocampus and cell-free cerebrospinal fluid. Neurobiol Aging 2014;35(1):152-8. [CrossRef]

17. Lusardi TA, Phillips JI, Wiedrick JT, Harrington CA, Lind B, Lapidus JA et al. MicroRNAs in human cerebrospinal fluid as biomarkers for Alzheimer's disease. J Alzheimers Dis 2017:55(3):1223-33. [CrossRef]

18. Manzine PR, Pelucchi S, Horst MA, Vale FAC, Pavarini SCl, Audano $\mathrm{M}$ et al. MicroRNA 221 targets ADAM10 mRNA and is downregulated in Alzheimer's disease. J Alzheimers Dis 2018;61(1):113-23. [CrossRef]

19. Dias IHK, Brown CL, Shabir K, Polidori MC, Griffiths HR. miRNA 933 expression by endothelial cells is increased by 27- hydroxycholesterol and is more prevalent in plasma from dementia patients. J Alzheimers Dis.2018;64(3):1009_ 17. [CrossRef]

20. Wu Y, Xu J, Xu J, Cheng J, Jiao D, Zhou C, Dai Y, Chen Q. Lower Serum Levels of miR-29c-3p and miR-19b-3p as Biomarkers for Alzheimer's Disease. The Tohoku journal of experimental medicine 2017;242(2):129-36. [CrossRef]
21. Yılmaz ŞG, Erdal ME, Özge AA, Sungur MA. Can Peripheral MicroRNA Expression Data Serve as Epigenomic (Upstream) Biomarkers of Alzheimer's Disease? OMICS 2016;20(8):45661. [CrossRef]

22. Li YY, Cui JG, Hill JM, Bhattacharjee S, Zhao Y, Lukiw WJ. Increased expression of miRNA-146a in Alzheimer's disease transgenic mouse models. Neurosci Lett 2011;487(1):94-8. [CrossRef]

23. Lukiw WJ, Zhao Y, Cui JG. An NF-kappaB-sensitive micro RNA-146a-mediated inflammatory circuit in Alzheimer disease and in stressed human brain cells. J Biol Chem 2008;283(46):31315-22. [CrossRef]

24. Sethi P, Lukiw WJ. Micro-RNA abundance and stability in human brain: specific alterations in Alzheimer's disease temporal lobe neocortex. Neurosci Lett 2009;459(2):100-4. [CrossRef]

25. Denk J, Boelmans K, Siegismund C, Lassner D, Arlt S, Jahn H. MicroRNA profiling of CSF reveals potential biomarkers to detect Alzheimer's disease. PLoS One 2015;10(5):e0126423. [CrossRef]

26. Kiko T, Nakagawa K, Tsuduki T, Furukawa K, Arai H, Miyazawa T. MicroRNAs in plasma and cerebrospinal fluid as potential markers for Alzheimer's disease. J Alzheimers Dis 2014;39(2):253-9. [CrossRef]

27. Cosín-Tomás M, Antonell A, Lladó A, Alcolea D, Fortea J, Ezquerra $M$, et al. Plasma miR-34a-5p and miR-545-3p as Early Biomarkers of Alzheimer's Disease: Potential and Limitations. Mol Neurobiol 2017;54(7):5550-62. [CrossRef]

28. Dong $H$, Li J, Huang L, Chen X, Li D, Wang T, et al. Serum MicroRNA Profiles Serve as Novel Biomarkers for the Diagnosis of Alzheimer's Disease. Dis Markers 2015;2015:625659. [CrossRef]

29. Maffioletti E, Milanesi E, Ansari A, Zanetti O, Galluzzi S, Geroldi C, et al. miR-146a Plasma Levels Are Not Altered in Alzheimer's Disease but Correlate With Age and IIIness Severity. Front Aging Neurosci 2020;11:366. [CrossRef]

30. Satoh J, Kino Y, Niida S. MicroRNA-Seq Data Analysis Pipeline to Identify Blood Biomarkers for Alzheimer's Disease from Public Data. Biomark Insights 2015;10:21-31. [CrossRef]

31. Persengiev $S$, Kondova I, Otting $N$, Koeppen $A H$, Bontrop RE. Genome-wide analysis of miRNA expression reveals a potential role for miR-144 in brain aging and spinocerebellar ataxia pathogenesis. Neurobiol Aging 2011;32(12):2316. e17-27. [CrossRef]

32. Persengiev SP, Kondova II, Bontrop RE. The Impact of MicroRNAs on Brain Aging and Neurodegeneration. Curr Gerontol Geriatr Res 2012;2012:359369. [CrossRef]

33. Cogswell JP, Ward J, Taylor IA, Waters M, Shi Y, Cannon B, et al. Identification of miRNA changes in Alzheimer's disease brain and CSF yields putative biomarkers and insights into disease pathways. J Alzheimers Dis 2008;14(1):27-41. [CrossRef]

34. Sarkar S, Jun S, Rellick S, Quintana DD, Cavendish JZ, Simpkins JW. Expression of microRNA-34a in Alzheimer's disease brain targets genes linked to synaptic plasticity, energy metabolism, and resting state network activity. Brain Res 2016;1646:139-151. [CrossRef]

35. Owczarz $M$, Budzinska $M$, Domaszewska-Szostek A Borkowska J, Polosak J, Gewartowska M, et al. miR34a and miR-9 are overexpressed and SIRT genes are downregulated in peripheral blood mononuclear cells of aging humans. Exp Biol Med (Maywood) 2017;242(14):145361. [CrossRef] 